\title{
Effects of nutrition on testicular growth in mature Merino rams actively immunized against $\mathrm{GnRH}$
}

\author{
M. J. Hötzel ${ }^{1 *}$, A. Caraty ${ }^{2}$ and G. B. Martin ${ }^{1,3 \dagger}$ \\ ${ }^{1}$ Faculty of Agriculture (Animal Science), The University of Western Australia, Nedlands, WA 6907, \\ Australia; ${ }^{2}$ INRA Station de Physiologie de la Reproduction des Mammifères Domestiques, \\ 37380 Nouzilly, France; ${ }^{3}$ CSIRO Division of Animal Production, Private Bag, PO Wembley, \\ WA 6014, Australia
}

\begin{abstract}
Nutrition-induced changes in testicular size in Merino rams appear to involve both GnRH-dependent and -independent pathways. This hypothesis was tested by feeding mature Merino rams that had been actively immunized against BSA or GnRH conjugated to BSA a diet that maintained initial body weight or the same diet supplemented daily with $1.5 \mathrm{~kg}$ of lupin grain. Blood was sampled every $20 \mathrm{~min}$ for $24 \mathrm{~h}$ on days $-1,19$ and 70 relative to the change in diet. The plasma was used to assess the effects of treatments on changes in LH, FSH and testosterone concentrations. In the group immunized against BSA, FSH increased in lupin-supplemented rams compared with maintenance-fed rams, while LH and testosterone were not affected by diet. In comparison, the concentrations of LH, FSH and testosterone were significantly lower in the group immunized against GnRH than in rams immunized against BSA, but none of these endocrine variables was affected by nutrition. With both immunization treatments, the testes were significantly larger in lupin-supplemented than in maintenance-fed rams. In the group immunized against BSA, this difference was caused by testicular growth in lupin-supplemented rams, whereas in the group immunized against $\mathrm{GnRH}$, lupin supplementation effectively maintained testicular mass, rather than allowed the regression observed in maintenance-fed rams. In conclusion, differences in testicular growth that were induced by dietary treatments in rams immunized against $\mathrm{GnRH}$ were not associated with changes in gonadotrophin or testosterone secretion. This supports the hypothesis that part of the effect of nutrition on testicular growth is independent of changes in GnRH secretion. The differences in testicular size observed in control rams were of similar magnitude to those observed in treated rams, but associated with large differences in plasma FSH concentrations, suggesting that this hormone plays an important role in this effect.
\end{abstract}

\section{Introduction}

In mature Merino rams, changes in nutrition can modulate testicular growth (Salamon, 1964; Lindsay et al., 1976, 1984; Oldham et al., 1978; Ritar et al., 1984; Schoeman and Combrink, 1987; Thwaites and Hannan, 1989; Martin et al., 1987, 1994a; Hötzel et al, 1995a) and the production of spermatozoa (Salamon, 1964; Oldham et al., 1978). These responses have also been demonstrated in rams of other breeds (Alkass $e t$ al. 1982; Lindsay et al., 1984) but, in the Merino, the responses are powerful enough to override the effects of photoperiod (Masters and Fels, 1984; Martin et al., 1994b, 1994c).

The classical view of regulation of testicular function is that the effects of internal and external stimuli (for example puberty,

\footnotetext{
*Present address: Departamento de Zootecnia, Centro de Ciências Agrárias, Universidade Federal de Santa Catarina, Caixa Postal 476, Rodovia SC $404 \mathrm{~km}$ 13, Bairro Itacorubi, Florianópolis, SC, Brazil.

${ }^{\dagger}$ Correspondence and reprint requests.

Received 6 December 1996.
}

photoperiod and social interactions) are relayed to the testis by the gonadotrophins, LH and FSH, the secretion of which is determined by changes in $\mathrm{GnRH}$ pulse frequency. However, the effect of nutrition appears to be mediated in a different way, because changes in testicular growth are poorly associated with changes in gonadotrophin secretion (Ritar et al, 1984; Martin et al., 1987, 1994a). Recent work has shown that the concentrations of LH and FSH do change shortly after a change in diet, but these responses are transient and values return to basal values after a few weeks while testicular growth continues (Martin et al,, 1994a). This finding led to the suggestion that the effects of nutrition on testicular growth in rams are partly independent of changes in $\mathrm{GnRH}$ secretion (Martin et al., 1994a). This view was reinforced by studies showing: (i) a high correlation between changes in body weight and in testicular growth (Murray et al., 1990); (ii) a similar dissociation between gonadotrophin patterns and nutrition-induced changes in testicular growth in goat bucks (Walkden-Brown et al., 1994), and (iii) even greater dissociation 
between gonadotrophin patterns and nutrition-induced effects on ovulation rate in sows and ewes (Cox et al., 1987; Ritar and Adams, 1988; Scaramuzzi and Campbell, 1990; Downing et al., 1995). The observations in females are supported by increases in ovarian activity, independent of effects on LH or FSH secretion, after metabolites or metabolic hormones are infused directly into the ovary (Cox et al., 1987; Downing and Scaramuzzi, 1991; Downing et al., 1995).

In a recent study this hypothesis was tested by imposing an exogenous regimen of high frequency GnRH pulses on rams, typical of the short-term response they experience on a supra-maintenance diet, and examining the effects on testicular growth in rams fed supra- or sub-maintenance diets (Hötzel et al, 1995a). The infusion of GnRH produced similar plasma profiles for LH, FSH and testosterone in rams fed the two diets, but testicular size was significantly reduced by undernutrition in rams receiving the exogenous $\mathrm{GnRH}$ infusion, supporting the hypothesis. The present complementary study further tested the hypothesis, by imposing low concentrations of $\mathrm{GnRH}$ by actively immunizing the rams against $\mathrm{GnRH}$. The effect of nutrition on the steroidogenic capacity of the testes of those rams was also determined.

\section{Materials and Methods}

\section{Animals and experimental design}

The experiment was carried out at the University of Western Australia (latitude $31^{\circ} 56^{\prime} \mathrm{S}$ ), under natural lighting. Photoperiod in this region ranges from $10 \mathrm{~h}$ light: $14 \mathrm{~h}$ dark in winter to $14 \mathrm{~h}$ light: $10 \mathrm{~h}$ dark in summer. At the beginning of the experiment, in mid-November (spring), it was about $13.5 \mathrm{~h}$ light:10.5 h dark. During the experiment, the animals were kept in individual pens with food provided once a day and fresh water available ad libitum. The experiment was preceded by an acclimatization period of 2 weeks during which the animals were fed $800 \mathrm{~g} \mathrm{day}^{-1}$ of a basal diet consisting of a mixture of oaten chaff with 10\% lupin grain (Lupinus angustifolius) and 3\% $(\mathrm{w} / \mathrm{w})$ mineral supplement (Siromin, CSIRO, Australia).

On day -1 of the experiment, 20 mature Merino rams were randomly allocated to treatments in a $2 \times 2$ factorial experiment with two diets and two types of immunization $(n=5$ per group), on the basis of body weight (mean \pm SFM: $60 \pm 1.9 \mathrm{~kg}$ ) and scrotal circumference (mean \pm SEM: $34.4 \pm 0.4 \mathrm{~cm}$ ). The rams were actively immunized against BSA (BSA-i) or against $\mathrm{GnRH}$ conjugated to BSA ( $\mathrm{GnRH}-\mathrm{i})$. Within each immunization treatment, half of the rams were fed $1 \mathrm{~kg}$ of the basal diet described above (maintenance diet) and the other half were fed the same diet supplemented with $1.5 \mathrm{~kg}$ lupin grain daily (high diet).

\section{Collection of blood samples}

Blood samples were taken every $20 \mathrm{~min}$ for $24 \mathrm{~h}$ on days - I and 19 and for $12 \mathrm{~h}$ on day $70(07: 00 \mathrm{~h}$ to $19: 00 \mathrm{~h})$ from polyethylene jugular cannulae fitted the day before. On day 77 testicular responsiveness was tested by an intravenous injection

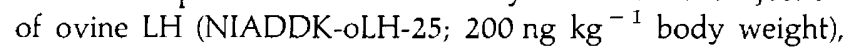
followed by blood sampling for $4 \mathrm{~h}$ at $30 \mathrm{~min}$ intervals, starting
10 min before the injection of $\mathrm{LH}$. Single blood samples were also taken each week by venepuncture and used to measure $\mathrm{GnRH}$ antibody titres and FSH concentrations. Every week, the rams were weighed and scrotal circumference was measured at the widest point with the animals standing and the testes hanging loosely in the scrotum. These procedures were carried out early in the morning before feeding.

\section{Immunization procedure}

The immunogen consisted of $1 \mathrm{mg} \mathrm{GnRH}$ conjugated to $4 \mathrm{mg}$ BSA by the glutaraldehyde reaction, as described by Caraty et al. (1980). The conjugate was lyophilized for storage and reconstituted in physiological saline before use. The first injection was emulsified in Freund's complete adjuvant (CSL, Parkville, Victoria, Australia) and consecutive booster injections were emulsified in incomplete Freund's adjuvant (CSL). A dose of $1 \mathrm{mg}$ antigen in a total volume of $5 \mathrm{ml}$ was injected subcutaneously in at least ten sites on the back of the animals on days $-10,1,10,20,30,40$ and 70 of the experiment. Control animals were injected with $4 \mathrm{mg}$ BSA emulsified in the same adjuvants.

\section{Assessment of GnRH antibody titres}

The tracer was (3-[I $\left.{ }^{125}\right]$ iodotyrosil-5)-GnRH that had been labelled with ${ }^{125}$ I by the chloramine- $\mathrm{T}$ method to specific activity $74 \mathrm{TBq} \mathrm{mmol}^{-1}$. On day 1 of the assay, $100 \mu \mathrm{l}$ samples that had been serially diluted (1:400, 1:2000 and 1:4000) in phosphate-buffered saline with $0.1 \%(\mathrm{w} / \mathrm{v})$ gelatin, $\mathrm{pH} 7.4$ (GPB) were incubated at room temperature with $100 \mu \mathrm{l}$ labelled GnRH and $200 \mu \mathrm{l}$ GPB. After $9 \mathrm{~h}, 100 \mu \mathrm{l}$ donkey anti-sheep serum (raised in our laboratory and diluted 1:20 in $\mathrm{GPB}$ ) was added and incubated overnight at $4^{\circ} \mathrm{C}$. On day 2 , $1 \mathrm{ml}$ GPB containing 6\% (w/v) polyethylene glycol 6000 was added; the tubes were centrifuged for $30 \mathrm{~min}$ at $2000 \mathrm{~g}$; the supernatant was aspirated and the amount of radioactivity in the peilet was measured. Titre was defined as the dilution of plasma that bound $30 \%$ of added tracer in the final volume of $400 \mu$ l.

\section{Hormone assays}

Luteinizing hormone was measured in all plasma samples. Follicle stimulating hormone was measured in the samples taken each week and in every seventh sample during each serial sampling (the mean for the whole period of serial sampling for each ram was used to calculate group means). Testosterone was measured in all the samples taken after the LH challenge and in every second sample taken on day 70 .

Plasma concentrations of $\mathrm{LH}$ were measured in all samples using the radioimmunoassay described by Martin et al. (1994a). The preparation CNRS-M3 (biopotency 1.8 IU NIH-LH-S1 $\mathrm{mg}^{-\mathrm{I}}$ ) used for reference was kindly supplied by $\mathrm{M}$. Jutisz (Collège de France). The tracer was prepared using NIDDKoLH-1-3 donated by the National Institute of Diabetes, Digestive and Kidney Disease (Baltimore, MD). The antiserum RI was raised in a rabbit in our laboratory and exhibited the following crossreactions; $100 \%$ with NIH-LH-S1, 97\% with 

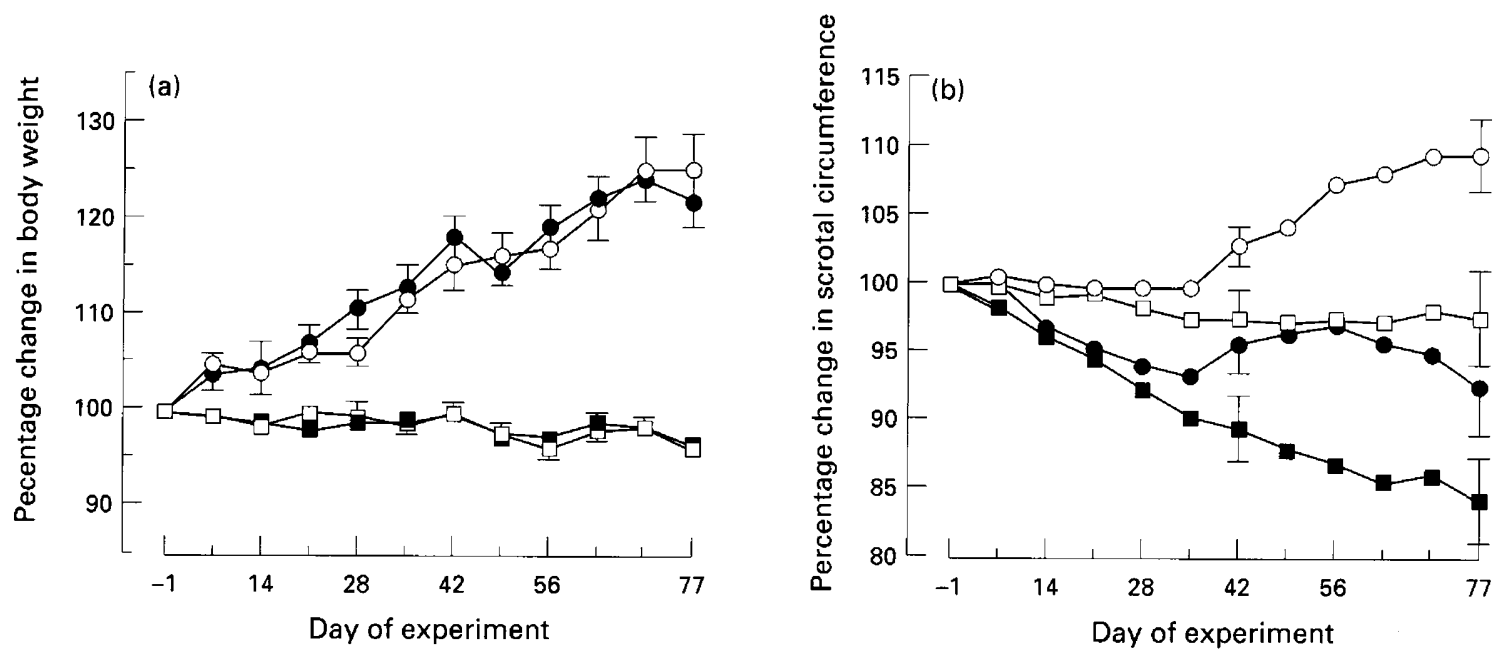

Fig. 1. Percentage change in (a) body weight and (b) scrotal circumference in mature Merino rams immunized against BSA and fed the high $(O)$ or the maintenance $(\square)$ diet, and in rams immunized against GnRH-BSA and fed the high $(\bullet)$ or the maintenance ( $\mathbf{\square})$ diet.

NIH-LH-S20, $18 \%$ with NIAMDD-oFSH-RP1, $0.93 \%$ with NIH-FSH-SI2, $8.2 \%$ with oGH and $5 \%$ with NIH-TSH-S8. The limit of detection of the standard curve (for all assays) was calculated by subtracting two standard deviations from the mean counts bound in nine replicates of the zero standard. Samples were assayed as duplicate $200 \mu \mathrm{l}$ aliquots and the limit of detection was $0.25 \mathrm{ng} \mathrm{ml}^{-1}$. Interassay coefficients of variation (mean \pm SEM) were $12.1 \pm 1.6 \%, 6.9 \pm 1.2 \%$ and $12.5 \pm 2.2 \%$, for quality controls containing $6.9,1.4$ and $0.6 \mathrm{ng}$ $\mathrm{ml}^{-1}$, respectively. The interassay coefficients of variation were $13.8 \%, 9.32 \%$ and $16.1 \%$, respectively.

Plasma concentrations of FSH were assayed by the method described by Martin $e$ al. (1994a) using a kit kindly supplied by the National Institute of Diabetes, Digestive and Kidney Disease. The kit comprised antiserum oFSH-I, reference preparation oFSH-RP-I (biopotency 75 IU NIH-FSH-SI $\mathrm{mg}^{-1}$ ) and tracer preparation oFSH-I-I. The samples were run in a single assay as duplicate $200 \mu \mathrm{l}$ aliquots and the limit of detection was $0.18 \mathrm{ng} \mathrm{ml}^{-1}$. Mean interassay coefficients of variation were $17.9,16.1$ and 7.1 for quality controls containing $6.2,3.4$ and $1.7 \mathrm{ng} \mathrm{ml}^{-1}$, respectively.

Plasma testosterone was measured using a non-extraction radioimmunoassay, as described by Hötzel et al. (1995a). The antiserum (Rabbit 3) was raised in our laboratory against testosterone-3-CMO-HSA. The preparation 4-androsten-17 $\beta$ ol-3-one (10 $\mu \mathrm{g} \mathrm{ml}^{-1}$; Sigma Chemicals $\mathrm{Co}$., MO) was used for reference and the tracer was 1,2,6,7-[ $\left.{ }^{3} \mathrm{H}\right]$ testosterone (Amersham International, Buckinghamshire). Crossreactions were $100 \%$ with testosterone, $70 \%$ with dihydrotestosterone, $3.7 \%$ with androstenedione, and less than $0.05 \%$ with progesterone, oestradiol, oestrone and oestriol. The limit of detection of the assay was $0.12 \mathrm{ng} \mathrm{ml}^{-1}$ and the interassay coefficients of variation (mean $\pm \mathrm{SEM}$ ) were $8.7 \%, 6.8 \%$ and $10.6 \%$ for quality controls containing 5.9, 3.4 and $0.4 \mathrm{ng} \mathrm{ml}^{-1}$, respectively.

\section{Statistical analysis}

Repeated measures analysis of variance was applied to all variables to test for interactions between the effects of diet and immunization. When main effects or interactions were significant $(P<0.05)$, one-way analysis of variance was applied within periods to test for interactions between the effects of diet and immunization at that time. Fisher's Protected LSD was used to test for differences between treatments within a period when appropriate. The FSH data were logarithmically transformed because the variance was directly proportional to the mean, but untransformed data are presented.

\section{Results}

\section{GnRH antibody titres}

Rams immunized against GnRH had a low antibody titre throughout the experiment, taking about 9 weeks to reach 1:400, the maximum titre reached. Rams immunized against BSA never displayed antibody titres above the nonspecific binding of the assay (mean $5.8 \%$ binding in 1:400).

\section{Change in body weight and scrotal circumference}

There were significant effects of diet $(P<0.0001)$ and the time $\times$ diet interaction $(P<0.0001)$ on the change in body weight (Fig. 1a). Immunization did not affect the rate of change in body weight throughout the experiment. Body weight increased in the rams fed the high diet and did not change in rams fed the maintenance diet, so that it differed significantly between the two diets at the end of the experiment $(P<0.001)$.

There was a significant effect of $\operatorname{diet}(P<0.004)$ and immunization $(P<0.0001)$ on the change in scrotal circumference (Fig. Ib) but no interactions between the effects of diet and immunization. On day 77, the difference in scrotal circumference between rams fed the high and maintenance diets was similar within each immunization group. The change in scrotal circumference was positive and higher $(P<0.01)$ in BSA-i rams fed the high diet than in any other group; GnRH-i rams fed the high diet and BSA-i rams fed the maintenance diet maintained 

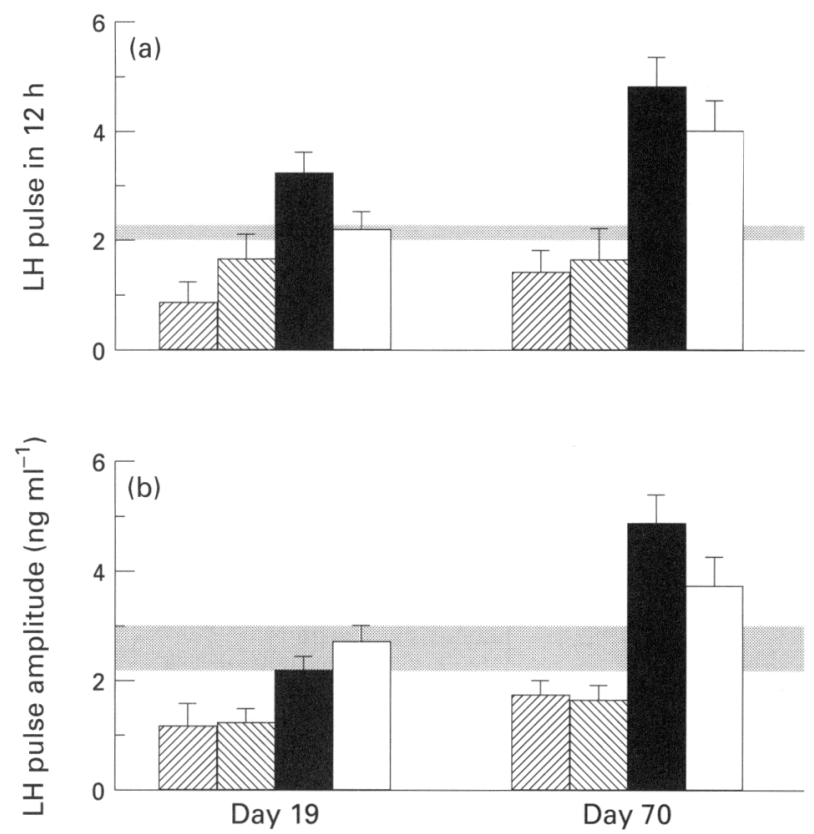

Fig. 2. The frequency (a) and amplitude (b) of LH pulses on days 19 and 70, in mature Merino rams immunized against GnRH-BSA and fed the high ( $(\mathbb{Z})$ ) or the maintenance $(\mathbb{\mathbb { N }})$ diet, and in rams immunized against BSA and fed the high ( $\boldsymbol{\square}$ ) or the maintenance $(\square)$ diet. Values on days 19 and 70 (means \pm SEM, $n=5$ per group) are compared with the pooled values from day -1 (shaded area, $n=20$ ).

their initial scrotal circumference throughout the experiment and did not differ from each other on day 77; scrotal circumference decreased during the experiment and was lower in GnRH-i rams fed maintenance than in any other group $(P<0.05)$.

\section{Testicular mass}

There was a significant effect of diet $(P<0.04)$ and immunization $(P<0.0001)$ on mean testicular mass measured at the end of the experiment. Amongst BSA-i rams, the testes were $28 \%$ heavier in those fed the high diet than in those fed the maintenance diet. Amongst GnRH-i rams, the testes were $33 \%$ heavier in those fed the high diet than in those fed the maintenance diet.

\section{Luteinizing hormone and follicle stimulating hormone}

There was a significant interaction between the effects of immunization and time on LH pulse frequency and mean LH pulse amplitude $(P<0.01)$. None of these variables differed among the groups on day -1 of the experiment, so the data were pooled for presentation (Fig. 2). On days 19 and 70, mean LH pulse frequency and mean LH pulse amplitude were lower in $\mathrm{GnRH}$-i rams than in BSA-i rams $(P<0.02)$, but did not differ between the diets.

Repeated measures analysis of variance revealed an effect $(P<0.05)$ of the interaction between diet, time and immunization on plasma FSH concentrations (Fig. 3a). The values were higher in BSA-i than in GnRH-i rams on day -1 of the experiment $(P<0.04)$, and remained different throughout the observation period. Diet affected mean FSH concentrations in BSA-i but not in GnRH-i rams. In BSA-i rams fed the high diet, FSH concentrations remained fairly constant until day 35 , and thereafter increased, to reach $450 \%$ of initial values by the end of the experiment (Fig. $3 \mathrm{~b}$ ), by which time they were significantly higher than those in all other groups $(P<0.03)$. In all the other groups, mean FSH concentrations remained relatively unchanged throughout the experiment.

\section{Testosterone}

Rams immunized against $\mathrm{GnRH}$ had significantly lower plasma testosterone concentrations than BSA-i rams on day 70 $(P<0.0005$; Fig. 4a). However, when adjusted to mean LH concentrations (calculated as ratio of mean testosterone: mean LH concentrations), there were no differences between treatments (Fig. 4b).

The injection of exogenous oLH on day 77 of the experiment produced a pulse of $\mathrm{LH}$ of similar amplitude $\left(5.5 \pm 0.39 \mathrm{ng} \mathrm{ml}^{-1}\right)$ in all treatment groups. The testosterone response to this challenge, calculated as area under the testosterone curve following the peak in plasma $\mathrm{LH}$, was lower in GnRH-i rams than in BSA-i rams ( $P<0.04$; Fig. 4c). Again, when testosterone was adjusted to mean LH concentrations (Fig. 4d), the groups did not differ from one another.

\section{Discussion}

In mature Merino rams, a high plane of nutrition effectively arrests the testicular regression induced by immunization against GnRH. The observation that nutrition can affect testicular size when GnRH is held at low concentrations adds a corollary to our recent study showing that nutrition can affect testicular size when GnRH is held at high concentrations (Hötzel et al., 1995a). These two complementary experiments both support the hypothesis that part of the effect of nutrition on testicular growth in mature rams is independent of changes in $\mathrm{GnRH}$ secretion.

The increase in scrotal circumference in control rams fed the high diet was associated with an increase in plasma FSH concentrations. However, in rams immunized against $\mathrm{GnRH}$, diet sustained testicular mass despite low concentrations of LH and FSH, so that testicular size was independent of changes in gonadotrophin secretion. This finding adds to several earlier studies that challenge the view that there is an obligatory association between long-term changes in gonadotrophin concentrations and testicular growth, at least when such growth is induced by changes in nutrition (Ritar et al., 1984; Martin et al., 1987, 1994a; Walkden-Brown et al., 1994). In control rams, the high diet increased testicular size rather than maintained it, so testicular growth is still dependent upon adequate gonadotrophic support. The ultimate effect of diet on testicular growth was of similar magnitude whether gonadotrophin concentrations were normal or lower than normal, suggesting that the GnRH-dependent and GnRH-independent mechanisms have additive effects on testicular mass. This might be because factors that affect testicular function at the intratesticular level have to interact with the gonadotrophins to either alter the Downloaded from Bioscientifica.com at 04/26/2023 12:23:11PM 

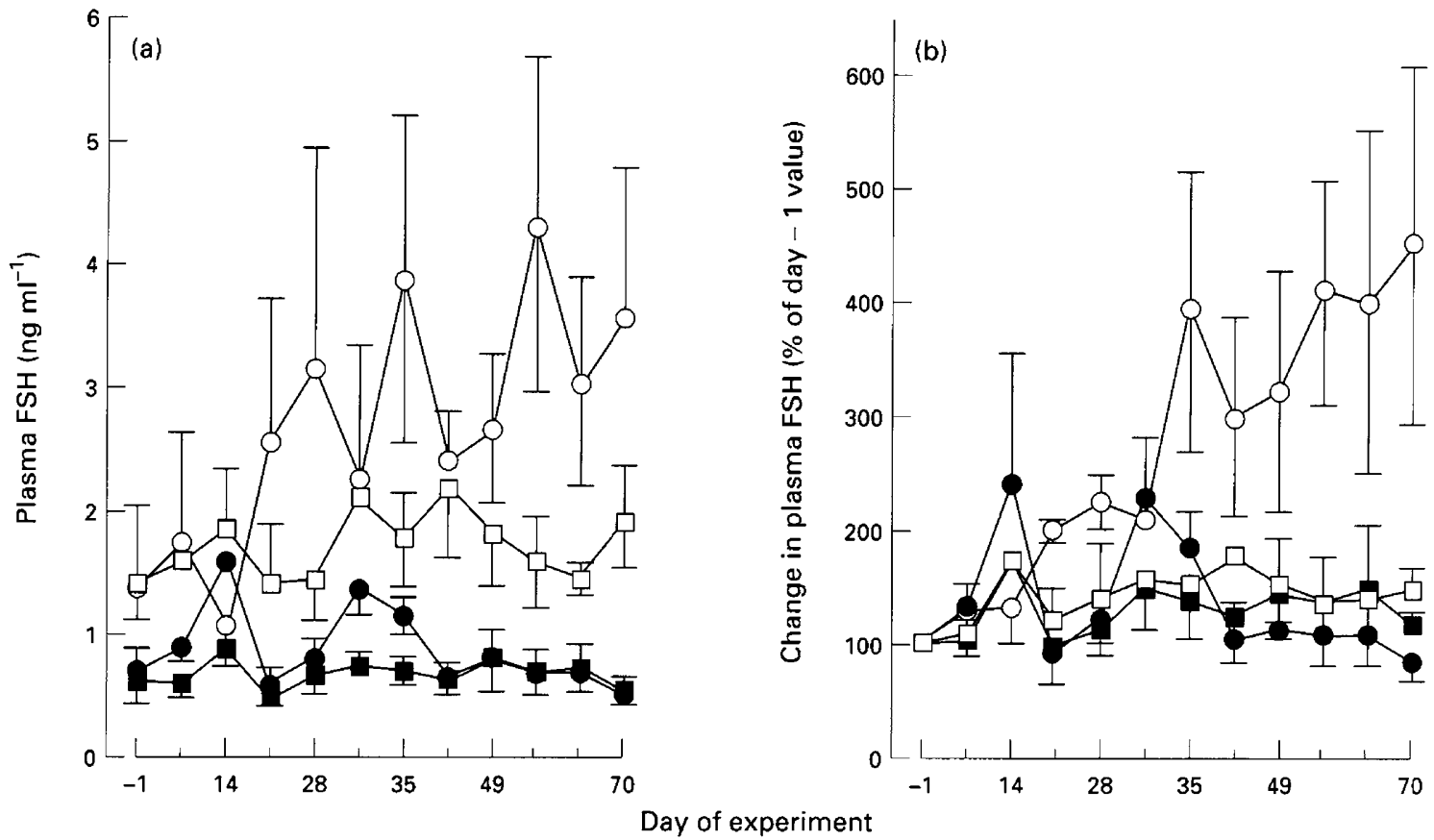

Fig. 3. (a) Mean ( \pm SEM) plasma concentrations of FSH and (b) change in mean plasma FSH concentrations in mature Merino rams immunized against BSA and fed the high $(O)$ or the maintenance $(\square)$ diet, and in rams immunized against GnRH-BSA and fed the high $(\mathbf{O})$ or the maintenance $(\boldsymbol{D})$ diet.

responsiveness of target cells to gonadotrophins or modulate their actions on these cells (Sharpe, 1984).

Testicular growth in control rams fed the high diet was not associated with an increase in LH pulse frequency on days 19 and 70 . This finding is consistent with our previous observation that LH pulse frequency is stimulated by an increase in diet but then returns to normal within 3-4 weeks (Martin et al., 1994a), that is, before the first intensive blood sampling in the present study. However, in the present experiment, the high diet led to a large increase in FSH concentrations that was sustained for a long period, as found by Hötzel et al. (1995a), suggesting that FSH plays an important role in the stimulatory effect of nutrition on testicular growth. This observation can be linked to the fact that, in the growing testis, the seminiferous tissue, but not the interstitial tissue, is developing (Hötzel et al., 1995b) and it is consistent with the relatively greater importance of FSH over LH in the control of spermatogenesis in rams (Courot, 1988; Kilgour et al., 1993, 1994).

While the lack of effect of diet on LH pulse frequency is consistent with previous findings (Ritar et al., 1984; Martin et al., 1987, 1994a), the sustained changes in FSH concentrations in this and the previous study (Hötzel et al., 1995a) contrast markedly with our initial observation that the concentrations return to basal values after a few weeks on the high diet (Martin et al., 1994a). This result is probably due to quantitative differences between these studies in the composition of the high (lupin-supplemented) diet. In the more recent experiments, twice as much lupin grain was used, and hence more protein and energy, and this led to sustained body growth, compared with the diet used by Martin et al. (1994a) with which body weight reached a plateau before the end of the experiment. Although this explains the sustained high FSH concentrations in recent experiments, it also supports our previous contention that LH and FSH respond differently to nutritional factors in intact rams fed a diet lower than maintenance (Martin et al, 1994a; Hötzel et al., 1995a). Since GnRH stimulates LH and FSH secretion by the pituitary gland (Lincoln, 1978), it appears that nutrition affects the pituitary mechanisms controlling FSH release. These observations cannot be explained by effects of diet on inhibin or testosterone secretion, because the production of these hormones does not appear to be affected by diet (Martin et al., 1994a; Hötzel et al., 1995a) and because similar effects are evident in castrated rams given exogenous inhibin and testosterone (Tjondronegoro et al., 1996). Alternatively, diet might alter FSH concentrations independently of changes in $\mathrm{GnRH}$ by affecting concentrations of activin, a factor that has been implicated in the paracrine regulation of FSH secretion (Carroll et al., 1991; Farnworth, 1995).

Within each immunization group, diet did not affect basal or LH-stimulated testosterone concentrations, reinforcing previous observations that nutrition does not affect steroidogenesis, despite the effects on testicular mass (Martin et al., 1994a; Hötzel et al., 1995a). Immunization against GnRH decreased peripheral concentrations of testosterone compared with control rams, but the lack of difference between the groups when testosterone was corrected for $\mathrm{LH}$ concentrations indicates that this was due to the lower LH stimulus in rams immunized against GnRH compared with control rams, rather than lower rates of steroidogenesis, suggesting that immunization against GnRH did not affect Leydig cell size or function. The effects of immunization against GnRH on steroidogenesis have been described in rats, in which lower testosterone secretion was associated with a decrease in the activity of $3 \beta$-hydroxysteroid dehydrogenase isomerase and reduced basal and hCG-stimulated activities of cholesterol side-chain 

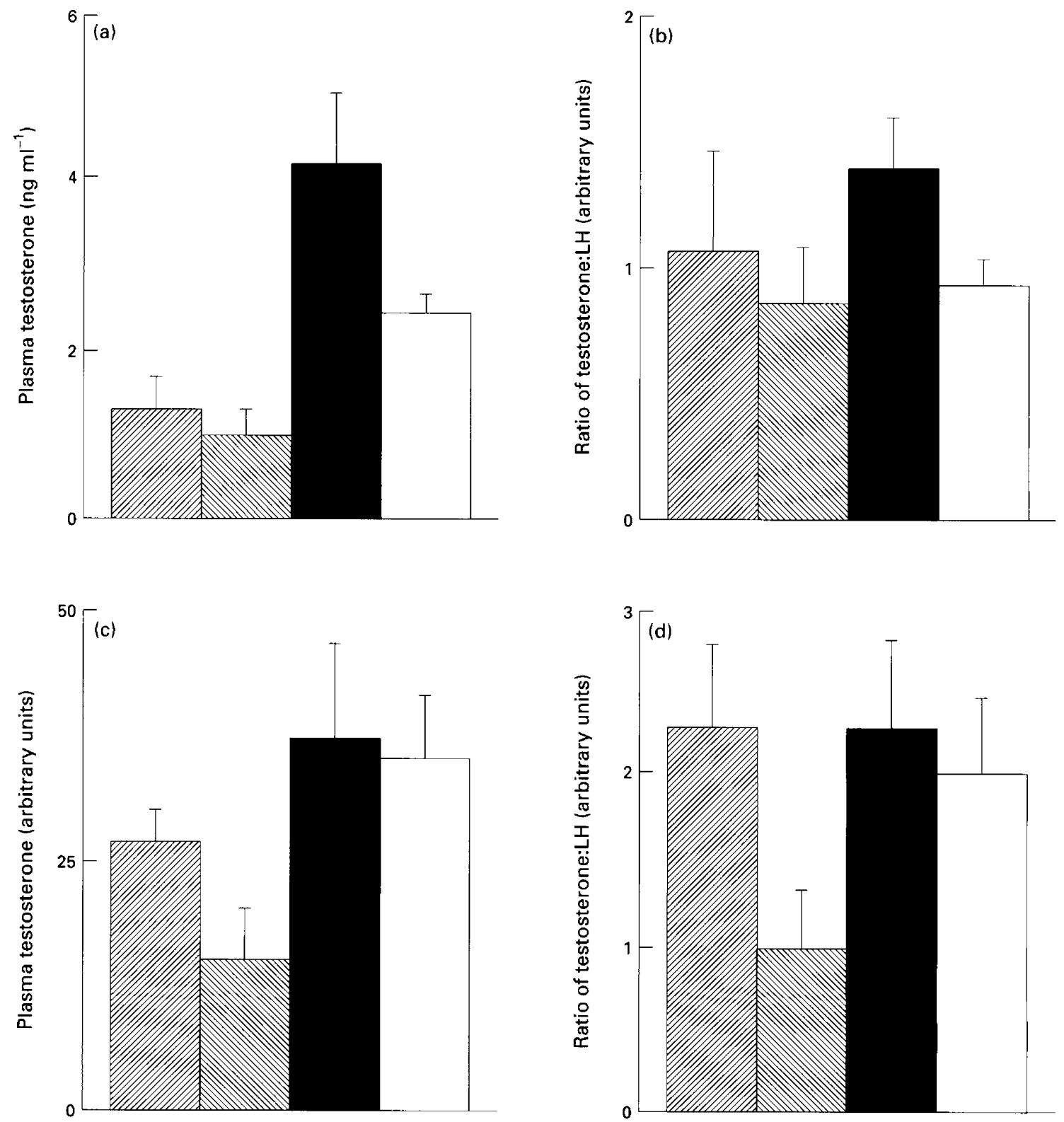

Fig. 4. Testosterone and LH secretion on day 70 in mature Merino rams immunized against GnRH-BSA and fed the high $(\mathbb{Q})$ or the maintenance $(\mathbb{E})$ diet, and in rams immunized against BSA and fed the high ( $\square$ ) or the maintenance ( $\square$ ) diet. Responses were studied by measurement of (a) mean plasma concentrations of testosterone and (b) the ratio between mean plasma concentrations of testosterone and LH over $12 \mathrm{~h}$ or (c) the area under the testosterone curve and (d) the ratio between the areas under the testosterone and LH curves after an injection of oLH. Values are mean \pm SEM and the areas are in arbitrary units.

cleavage and $17 \alpha$-hydroxylase (Chase et al., 1992). It is possible that a longer reduction of gonadotrophin concentrations than that achieved in this study is required to alter the steroidogenic capacity of the ram testis. In this study there was a trend for a lower testosterone response to $\mathrm{LH}$ in the GnRH-i rams fed the maintenance diet, suggesting that diet may interact with gonadotrophins in the regulation of steroidogenesis (Sharpe, 1984; Kerr and Sharpe, 1985; Kerr et al., 1988).

In conclusion, this study adds further support to the hypothesis that part of the effect of nutrition on testicular growth in mature rams is independent of changes in GnRH secretion.
The relative effect of diet on testicular growth was of the same magnitude whether gonadotrophin concentrations were normal or lower than normal, suggesting an additive effect of GnRHdependent and -independent mechanisms on the testes. The present results indicate that, although nutrition can alter testicular growth in the absence of changes in plasma gonadotrophins, the mechanism(s) by which it causes this growth depends on the concurrent presence of the gonadotrophins. Finally, the patterns of gonadotrophins observed in this study also suggest that FSH is likely to play a more important role than $\mathrm{LH}$ in this effect. 
This study could not have been contemplated without the generous assistance of the students and staff of the Animal Science Group (University of Western Australia) and the CSIRO Division of Animal Production. We are particularly indebted to K. L. Shepherd and M. A. Blackberry. The authors are also grateful to the National Institute of Diabetes, Digestive and Kidney Disease, the Center for Population Research of the National Institute of Child Health, and the Agricultural Research Service of the US Department of Agriculture, as well as the University of Maryland School of Medicine, for the reagents for the LH and FSH assays. They would like to acknowledge R. I. Cox (CSIRO Division of Animal Production, Prospect, NSW) for the donation of testosterone-3-CMO-HSA. M. J. Hötzel was supported by the Brazilian Research Council ( $\mathrm{CNPq})$. This work was funded by the Australian Research Council and the CSIRO Division of Animal Production.

\section{References}

Alkass JE, Bryant MJ and Walton JS (1982) Some effects of level of feeding and body condition upon sperm production and gonadotropin concentrations in the ram Animal Production 34 265-277

Caraty A, de Reviers M-M, Pelletier J and Dubois MP (1980) Reassessment of LRF radioimmunoassay in the plasma and hypothalamic extracts of rats and rams Reproduction, Nutrition, Développement 20 1489-1501

Carroll RS, Kowash PM, Logfren JA, Schwall RH and Chin WW (1991) In vivo regulation of FSH synthesis by inhibin and activin Endocrinology 129 3299-3304

Chase DJ, Karle JA and Fogg RE (1992) Maintenance or stimulation of steroidogenic enzymes and testosterone production in rat Leydig cells by continuous and pulsatile infusions of luteinizing hormone during passive immunization against gonadotrophin-releasing hormone journal of Reproduction and Fertility 95 657-667

Courot M (1988) The effects of gonadotrophins on testicular function (spermatogenesis) Proceedings of the 11th International Congress on Animal Reproduction and Artificial Insemination 5 311-319

Cox NM, Stuart MJ, Althen TG, Bennett WA and Miller HW (1987) Enhancement of ovulation rate in gilts by increasing dietary energy and administering insulin during follicular growth Journal of Animal Science 64 507-516

Downing JA and Scaramuzzi RJ (199I) Nutrient effects on ovulation rate, ovarian function and the secretion of gonadotrophic and metabolic hormones in sheep Journal of Reproduction and Fertility Supplement 43 209-227

Downing JA, Joss J and Scaramuzzi RJ (1995) A mixture of the branched chain amino acids leucine, isoleucine and valine increases ovulation rate in ewes when infused during the late luteal phase of the oestrous cycle: an effect that may be mediated by insulin Journal of Endocrinology 145 315-323

Farnworth, PG (1995) Gonadotrophin secretion revisited. How many ways can FSH leave a gonadotroph? Journal of Endocrinology 145 387-395

Hötzel MJ, Walkden-Brown SW, Blackberry MA and Martin GB (1995a) The effect of nutrition on testicular growth in mature Merino rams involves mechanisms that are independent of changes in $\mathrm{GnRH}$ pulse frequency Journal of Endocrinology 147 75-85

Hötzel MJ, Markey CM, Walkden-Brown SW, Blackberry MA and Martin GB (1995b) Effects of nutrition on testicular morphology and endocrinology in rams Proceedings of the Annual Conference of the Australian Society for Reproductive Biology 27115

Kerr JB and Sharpe RM (1985) Follicle-stimulating hormone induction of Leydig cell maturation Endocrinology 116 2592-2604

Kerr JB, Risbridger GP, Murray PJ and Knell CM (1988) Effect of unilateral cryptorchidism on the intertubular tissue of the adult rat testis: evidence for intracellular changes within the Leydig cells International Journal of Andrology 11 209-223

Kilgour RJ, Courot M, Pisselet C, Dubois MP and Sairam MR (1993) Inhibition of FSH affects spermatogenesis in the mature ram Animal Reproduction Science 32 213-225
Kilgour RJ, Courot M, Pisselet C, Dubois MP and Sairam MR (1994) Inhibition of FSH but not LH affects spermatogenesis in the mature ram Animal Reproduction Science 34 253-264

Lincoln GA (1978) The temporal relationship between plasma levels of FSH and LH in the ram Journal of Reproduction and Fertility 53 31-37

Lindsay DR, Gherardi PB and Oldham CM (1976) The effect of feeding a high protein supplement before joining on testicular volume of rams Proceedings of International Sheep Breeders Congress 294-298

Lindsay DR, Pelletier J, Pisselet C and Courot M (1984) Changes in photoperiod and nutrition and their effect on testicular growth of rams Journal of Reproduction and Fertility $71351-356$

Martin GB, Sutherland SRD and Lindsay DR (1987) Effects of nutritional supplements on testicular size and the secretion of $\mathrm{LH}$ and testosterone in Merino and Booroola rams Animal Reproduction Science 12 267-281

Martin GB, Tjondronegoro $S$ and Blackberry MA (1994a) Effects of nutrition on testicular size and the plasma concentrations of gonadotrophins, testosterone and inhibin in mature male sheep Journal of Reproduction and Fertility 101 $121-128$

Martin GB, Walkden-Brown SW, Boukhliq R, Tjondronegoro S, Miller DW, Fisher JS, Hötzel MJ, Restall BJ and Adams NR (1994b) Non-photoperiodic inputs into seasonal breeding in male ruminants. In Perspectives in Comparative Endocrinology pp 574-585 Eds KG Davey ef al. National Research Council of Canada, Ottawa

Martin GB, Fisher JS, Blackberry MA, Boukhliq R, Hötzel MJ, Miller DW, Shepherd KS and Walkden-Brown SW (1994c) Nutritional and photoperiodic control of testicular size in Suffolk and Merino rams Proceedings of the Annual Conference of the Australian Society of Animal Production 20427

Masters DG and Fels HE (1984) Seasonal changes in the testicular size of grazing rams Proceedings of the Conference of the Australian Society of Animal Production 15 444-447

Murray PJ, Rowe JB, Pethick DW and Adams NR (1990) The effect of nutrition on testicular growth in the Merino ram Australian Journal of Agricultural Research 41 185-195

Oldham CM, Adams NR, Gherhadi PB, Lindsay DR and Mackintosh JB (1978) The influence of level of feed intake on sperm-producing capacity of testicular tissue in the ram Australian Journal of Agricultural Research 29 173-179

Ritar AJ and Adams NR (1988) Increased ovulation rate, but not FSH or LH concentrations, in ewes supplemented with lupin grain Proceedings of the Australian Society of Animal Production 17 310-313

Ritar AJ, Adams NR and Sanders MR (1984) Effect of lupin feeding on LH, testosterone and testes. In Reproduction in Sheep pp 76-48 Eds DR Lindsay and DT Pearce. Australian Academy of Science, Canberra

Salamon S (1964) The effect of nutritional regimen on the potential semen production of rams Australian Journal of Agricultural Research 15 645-656

Scaramuzzi RJ and Campbell BK (1990) Physiological regulation of ovulation rate in the ewe: a new look at an old problem. Reproductive physiology of Merino sheep In Reproductive Physiology of Merino Sheep: Concepts and Consequences pp 71-84 Eds CM Oldham GB Martin and IW Purvis, University of Western Australia Press, Perth

Schoeman SJ and Combrink GC (1987) The influence of dietary supplementation on testicular growth rate in adult Merino rams South African Journal of Animal Science 17 43-45

Sharpe RM (1984) Intratesticular factors controlling testicular function Biology of Reproduction 30 29-49

Thwaites CJ and Hannan GD (1989) The effects of frequency of ejaculation and undernutrition on the size and tone of the ram's testes Animal Reproduction Science $1929-35$

Tjondronegoro S, Martin GB, Sutherland SRD and Boukhliq R (1996) Interactions between nutrition, testosterone and inhibin in the control of gonadotrophin secretion in mature rams Reproduction, Fertility and Development 8 855-862

Walkden-Brown SW, Restall BJ, Norton BW, Scaramuzzi RJ and Martin GB (1994) Effect of nutrition on seasonal patterns of peripheral LH, FSH and testosterone concentration, testicular mass, sebaceous gland volume and odour in male Australian cashmere goats Journal of Reproduction and Fertility $\mathbf{1 0 2}$ $352-360$ 